\title{
PSYCHE
}

Vol. $61 \quad$ March, $1954 \quad$ No. 1

\section{A NEW MYRMECOPHILOUS SCARABAEID BEETLE FROM THE PHILIPPINE ISLANDS WITH A REVIEW OF HAROLDIUS ${ }^{1}$}

By Pe. F. S. Pereira C.M.F.

Departamento de Zoologia, São Paulo, Brasil

I have recently received from Dr. P. J. Darlington a short series of a scarabaeid beetle of the genus Haroldius from the Philippines. According to Dr. Darlington, who collected them, "All 6 specimens of the beetle were taken in one nest of ants under a stone in forest. Dr. W. L. Brown tells me that the ant is a Diacamma of the group vagans F. Smith of the tribe Ponerini." The specimens are markedly different from Haroldius globosus, the only species of the genus previously known from the Philippines.

Dr. Darlington has kindly donated two of the specimens to the Departamento de Zoologia; one of these has been dissected and upon examination of the genitalia proved to be a female. No sexual dimorphism being apparent in undissected specimens, I have decided not to attempt a study of the male genitalia until more material is available.

\section{Haroldius philippinensis, $\mathrm{n}$. sp.}

(Figs. 1-10)

Length: $3.5-4.0 \mathrm{~mm}$; humeral width: $2.5-3.0 \mathrm{~mm}$.

Shape oval, broadest at middle of elytra; color black with brown overtones on anterior margin of clypeus, sides of elytra, legs, and under parts of body.

${ }^{1}$ Published with a grant from the Museum of Comparative Zoology at Harvard College. 
Head: Clypeus (fig. 2) finely punctate, more densely so in front, its anterior margin with sharp parallel denticles separated at base by a well-defined longitudinal sulcus. Genae separated from clypeus by one well-defined sulcus, not denticulate in front; posterior angles acute. Dorsal aspect of eyes small. Mouth-parts (figs. 1, 4) with 4-segmented labial palpi ; first segment short and robust; second shorter and thinner than first; third as long as. first plus second, thicker than either, oval-shaped; all three proximal segments with bristles; fourth segment thin and short. Maxillary palpi also 4-segmented; first segment very short and thin; second much longer than first, apically dilated; third with sub-parallel sides, a little longer than first, as thick as apex of second; fourth much longer than three proximal ones together, a little thinner than third, narrowed towards tip. Antennae (fig. 3) 8-segmented, first segment much longer than four next ones together, with a median constriction; second and third sub-equal, subcylindrical, third somewhat dilated towards apex; fourth and fifth sub-equal, shorter than third, wider than long; sixth to eighth forming lamellae of decreasing size, of which first is much longer than third to fifth segments together; second lamella sub-equal to first; third lamella much shorter.

Prothorax: pronotum (fig. 2) much broader than long, smooth, with a series of elongate punctures near posterior angles, vanishing towards middle; a small round fovea in front of each posterior angle; no foveae on sides; anterior angles rounded, posterior poorly-defined. Anterior part of prosternum with a deep depression, separated from posterior part by a keel which runs from near coxae to lateral margin of prosternum; prosternal process very wide, smooth.

Mesothorax: Scutellum completely covered by elytra; its anterior part opaque, with numerous punctures and small bristles; posterior part triangular, smooth. Mesoster-

\section{Explanation of Plate 1}

Haroldius philippinensis, n. sp. 1. Labial palpi. 2. Dorsal view of head and pronotum. 3. Antenna. 4. Maxillary palpi. 5. Wing. 6. Spermatheca. 7. Claws (much enlarged). 8. Foreleg. 9. Middle leg. 10. Hind leg. Figs. 3, 4, 6, 8, 9, 10 on the same scale. 

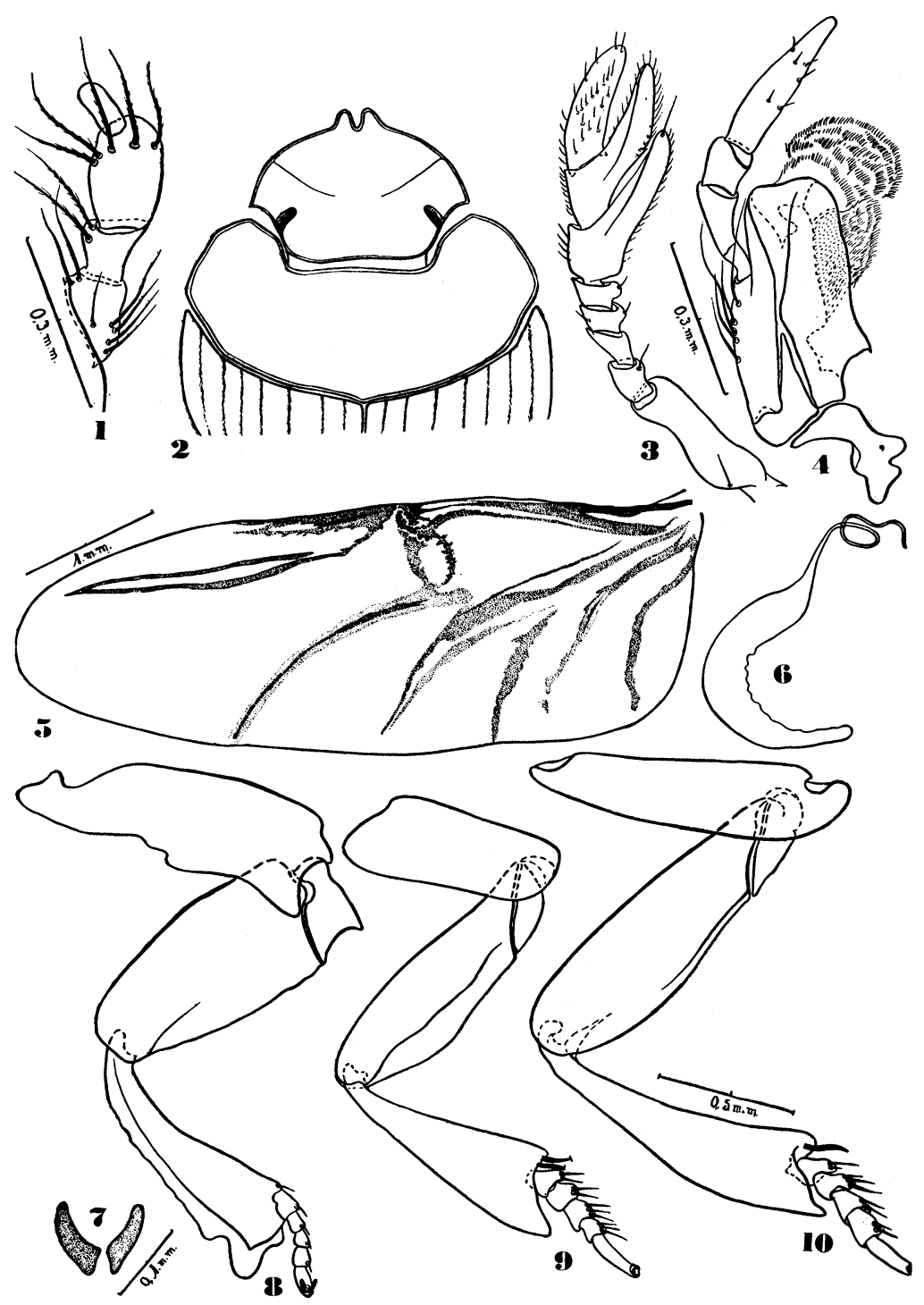

Pereira - Haroldius philippinensis 
num smooth, very wide and long, separated from metasternum by an arcuate suture. Mesoepisterna broad, subquadrangular.

Metathorax: Metasternum smooth, very broad between coxae, a little swollen on middle. Metaepisternum wide in front, narrower behind.

Abdomen: Six segments visible at middle, finely punctate; second, third, and fourth segments sub-equal; fifth much longer than fourth; sixth still longer. Posterior sternites with round marginal foveae. Pygidium swollen, with small punctures (visible only under strong magnification); its basal portion weakly emarginate.

Elytra smooth, with seven very weak, not obvious striations, which are not punctate. Interstriae flat, with two rows of pits with microscopic yellow bristles, effaced posteriorly. Anterior angle of elytra acute, produced forward. Epipleurae very wide, with very fine punctures on anterior half, more strongly sculptured posteriorly.

Forelegs: Coxae (fig. 8) long, transverse, with very fine, short pubescence. Trochanters sub-globose, dentate at internal apices. Femora robust, with punctures and small bristles on under surface of apex; anterior face strongly excavated along its entire length. Tibiae a little longer than femora but more slender; thinner basally, gradually dilated apically; only two latero-apical spines and one angular process on middle of anterior margin; upper and lateral faces very finely sculptured and with microscopic bristles; inner and outer faces with somewhat larger bristles. Spurs very short and thin, bristle-like. Tarsi set in foveae at inner corners of tibiae; first segment small, partly hidden in the fovea, so that sometimes only four segments are visible; second, third and fourth segments sub-equal, four-sided, elongate, curved, with narrow tips; fifth segment a little longer than third plus fourth, ending in two short, robust claws.

Middle legs: Coxae (fig. 9) smooth, widely separated, almost parallel (slightly convergent backwards). Trochanters small and elongate. Femora less robust than anterior ones. Tibiae shorter than femora, and much more dilated towards apex, with very minute yellow bristles on upper and lower faces; inner faces with bristle-bearing keels; 
outer faces strongly excavated. Spurs minute, bristle-like. Tarsi robust; first, second, and third segment sub-globose, slightly dilated on inner side; fourth segment more cylindrical, a little longer than any of others; each of four basal segments with an internal tuft of bristles; fifth tarsal segment thinner than others, cylindrical, narrower at apex, a little longer than third plus fourth. Claws similar to those of forelegs.

Hind legs: Coxae (fig. 10) long, transversely placed. Trochanters more triangular than middle ones, with some bristles. Femora much longer than middle ones; under surface smooth; one keel on anterior margin; posterior face excavated. Tibiae much shorter than femora, less dilated towards apex than middle tibiae but more strongly arched. Spurs bristle-like. Tarsi similar to those of fore and middle legs.

The present species can be distinguished from Haroldius globosus by the following table:

H. philippinensis $\mathrm{n}$. sp.

Larger $(3.5-4.0 \mathrm{~mm}$.)

Black with brownish overtones on

front of clypeus, elytra, under parts, and legs

Elytra pubescent, with striae visible on anterior half and effaced posteriorly
H. globosus Boucomont 1925

Smaller $(2.0 \mathrm{~mm}$.)

Metallic green with a slight purplish sheen

Elytra glabrous, with striae effaced on disc

Type-locality: Dingalan Bay, East Luzon, Philippine Islands.

Type-material: Type and 3 paratypes in the Museum of Comparative Zoology at Harvard College; 2 paratypes (one dissected and mounted on slides) in the Departamento de Zoologia, São Paulo. All collected by P. J. Darlington (VII-VIII, 1945) at the type-locality, in a nest of ants of the genus Diacamma (group vagans F. Smith, Ponerini).

This genus is scarce in collections. The biology of the species is poorly known. Some of them have been found in ant nests $(H$. heimi with Pheidole latinoda, the present species with Diacamma). H. perroti has been collected with numerous specimens of Bacanius (Coleop., Histeridae) by sifting dead leaves. 
A list of the species of Haroldius

Type of genus: H. fairmairei Bouc., by designation of Paulian 1945, 58.

1. H. calcaratus Janssens 1934, 33, figs. 1-2. Barway (India).

2. H. cardoni Boucomont 1923, 83; Arrow 1931, 414; Paulian 1934, 164. Chota Nagpur.

3. H. chapmani Paulian 1934, 163. Bangalore.

4. H. fairmairei Boucomont 1914, 254 ; Paulian 1934, 164. Singapore.

5. H. fleutiauxi Paulian 1945, 60. Tonkin.

6. H. globosus Boucomont 1925, 151. Philippines.

7. H. heimi Wassman 1918, 4, pl. 1, fig. 1 (Cyclotrogus); Arrow 1931, 414-415; Paulian 1934, 164. (Syn.: Cyclotrogus nigrita Wassman loc. cit.). Bengal; Bombay.

8. H. oberthüri Paulian 1934, 163 . India.

9. H. perroti Paulian 1939,$70 ; 1943$, 262, fig. $132 ; 1945$, 160. Tonkin.

10. H. philippinensis n. sp. Philippines.

11. H. rugatulus Boucomont 1914, 253 ; Paulian 1934, 164. Singapore.

12. H. stevensi Arrow 1931, 414, 416, fig. 60 ; Paulian 1934, 164. Bengal.

Ponerotrogus annandalei Silvestri 1924 (Rec. Indian Mus. 26, p. 586, figs. 1-2), collected by Annandale in a nest of Ponera tesserinoda Mayr [now = Bothroponera sulcata (Frauenfeld) ], under stones on the Barkuda Islands, Chilka Lake, seems to have characters similar to those of Haroldius; the two genera are possibly synonymous.

\section{Provisional key to the species of Haroldius}

1. Clypeus not emarginate, with no denticles on anterior margin; middle and hind spurs longer than four basal tarsal segments together; meso-metasternal suture straight; anterior tibiae quadridentate; 2.5 mm.; Barway

1) H. calcaratus Janss.

$1^{\prime}$. Clypeus dentate; middle and posterior spurs short, only longer than first tarsal segment; meso-metasternal suture arcuate 
2. Basal portion of pronotum with a central triangular

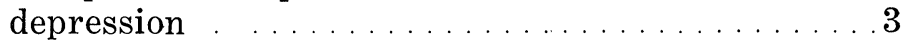

2'. Basal portion of pronotum without such a depression. 5

3. Sides of pronotum with oblique striae near posterior margin ; 2.5-3.0 mm.; Bombay . .2) H. heimi Wassm.

3 . Sides of pronotum punctate, not striate 4

4. Large, $3.5 \mathrm{~mm}$.; Bengal

3) H. stevensi Arr.

4'. Small, $1.5 \mathrm{~mm}$.; Singapore

4) H. fairmairei Bouc.

5. Bases of pronotum with oblique striae ... . .6 6

$5^{\prime}$. No such striae . . . . . . . . . . . . . . . . . . 7

6. Elytral interstriae each with one row of setiferous punctures; fore part of body cupreous, hind part black; 2 mm.; Tonkin ........5) H. fleutiauxi Paul.

6 . Interstriae each with two rows of setiferous punctures; black or brown; $2.5 \mathrm{~mm}$.; Singapore

7. Elytra glabrous

6) H. rugatulus Bouc.

7'. Elytra pubescent

8. Elytral striae almost effaced on disc; metallic green with slight purplish sheen; $2 \mathrm{~mm}$.; Philippines

7) H. globosus Bouc.

8'. Elytral striae evident even on disc; upper parts brown or cupreous; under parts lighter; basal part of antennae grayish; $1.9 \mathrm{~mm}$.; Tonkin

8) H. perroti Paul.

9. Elytral interstriae each with one row of setiferous punctures; $3 \mathrm{~mm}$.; Chota Nagpur

9) H. cardoni Paul.

$9^{\prime}$. Interstriae each with two rows of setiferous punctures

10. One longitudinal sulcus immediately behind anterior denticles of clypeus; 3.5-4.0 mm.; Philippines 10) H. philippinensis n. sp.

$10^{\prime}$. No such sulcus

11 Clypeus with strong, dense punctures; pronotum with strong, dense punctures on anterior half, and fine, scattered ones on posterior half; $3 \mathrm{~mm}$.; Chota Nagpur ...............11) H. chapmani Paul.

11'. Clypeal and pronotal punctures fine and sparse; 2.53.0 mm.; Chota Nagpur .... 12) H. oberthüri Paul. 


\section{Acknowledgements}

I am indebted to Dr. Philip J. Darlington, Jr., Curator of Insects, Museum of Comparative Zoology at Harvard College, for the opportunity of describing this interesting new form, as well as for the gift of two specimens to the Departamento de Zoologia. To Mrs. M. A. V. d'Andretta, of the latter institution, I am indebted for the drawings which illustrate the description. Dr. P. E. Vanzolini has kindly translated the manuscript into English.

Arrow, G.

BIBLIOGRAPHY

1931. Fauna of British India including Ceylon and Burma. Lamellicornia III. London. xii +428 pp., 13 pls., 1 map.

Boucomont, A.

1914. Les Coprophages de l'Archipel Malais. Ann. Soc. Ent. France 83: 238-350.

1923. Notes sur divers Coléoptères coprophages. Bull. Mus. Hist. Nat. Paris 29: pp. 81-83.

1925. Lamellicornes Coprophages des Iles Philippines. Bull. Soc. Ent. France: 151-154.

JANSSENS, A.

1934. Description d'un Haroldius nouveau. Bull. Soc. Ent. Belgique 74: 33-34, 2 figs.

Paulian, R.

1934. Quelques Panelini Asiatiques nouveaux ou peu connus. Bull. Soc. Ent. France: 162-164.

1939. Quelques nouvelles espèces de Coléoptères Lamellicornes. Bull. Soc. Ent. France: 68-74, 3 figs.

1943. Les Coléoptères, Forms, Moeurs, Rôle. Paris. 396 pp., 14 pls.

1945. Coléoptères Scarabéides de l'Indochine. I. Paris. 225 pp., 105 figs., 1 map.

WASSMAN, E.

1918. Myrmecophile und termitophile Coleopteren aus Ostindien, hauptsächlich gesammelt von P. v. Assmuth S. J. Wiener Ent. Zeit. 37: 1-23, 2 pls. 

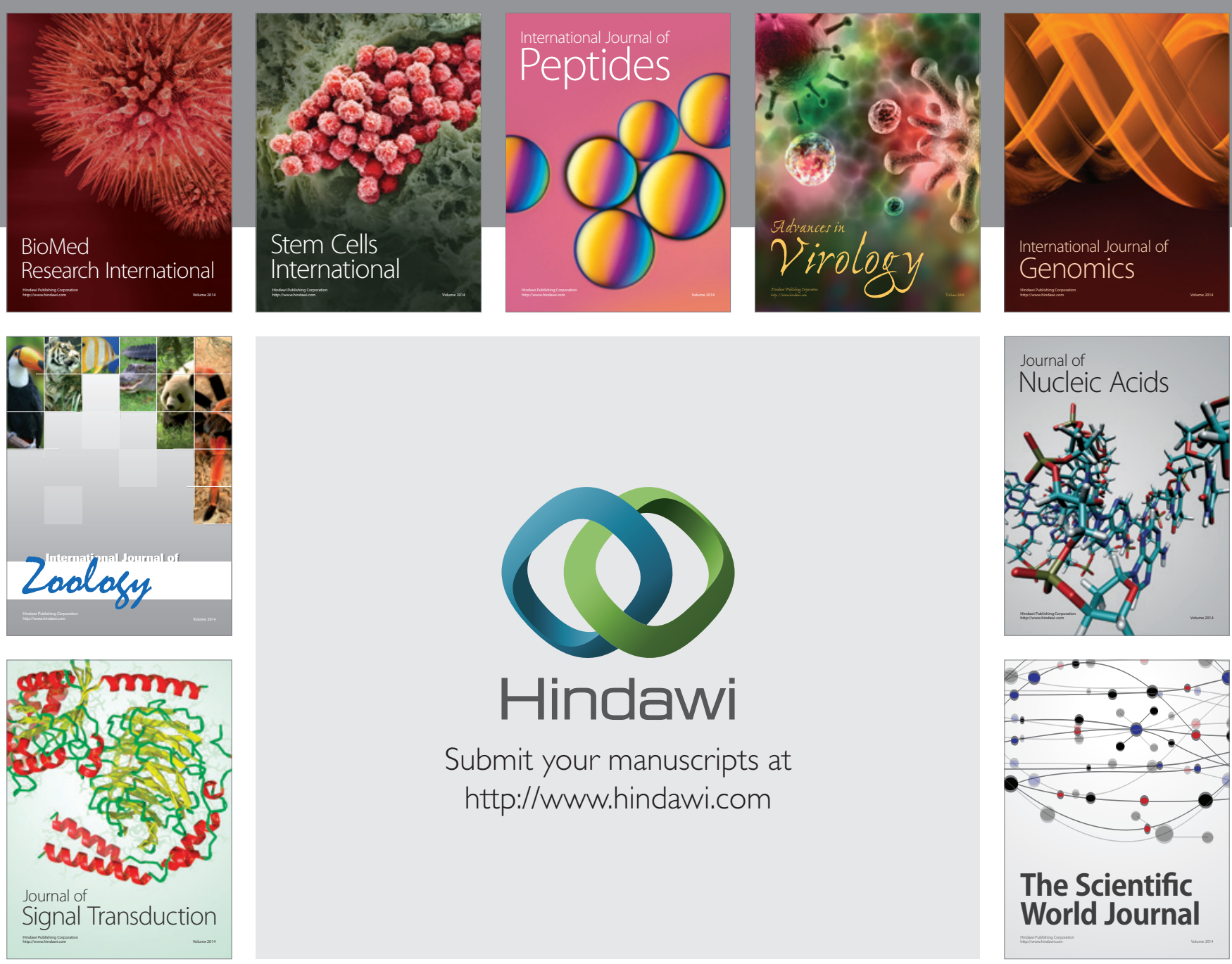

Submit your manuscripts at

http://www.hindawi.com
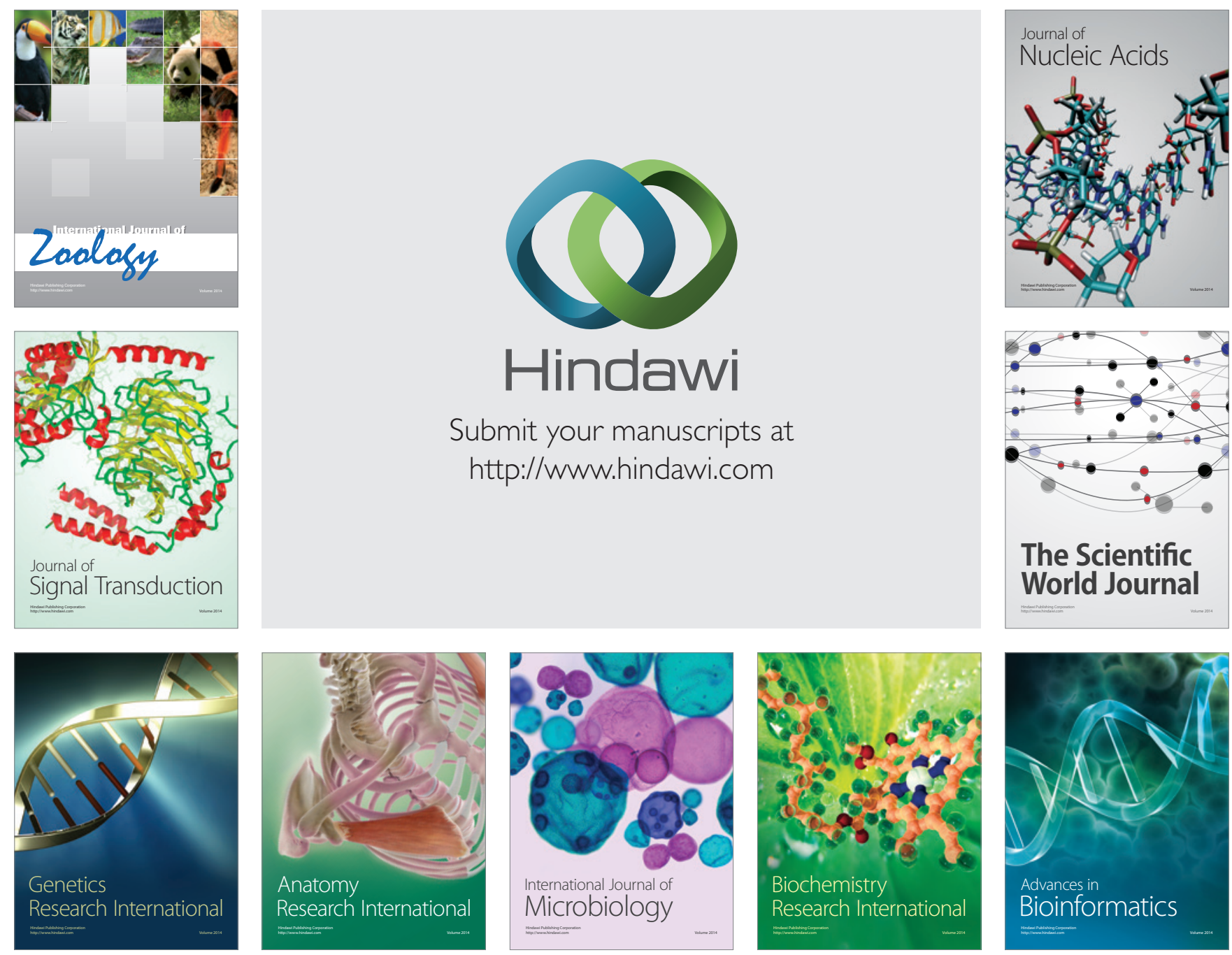

The Scientific World Journal
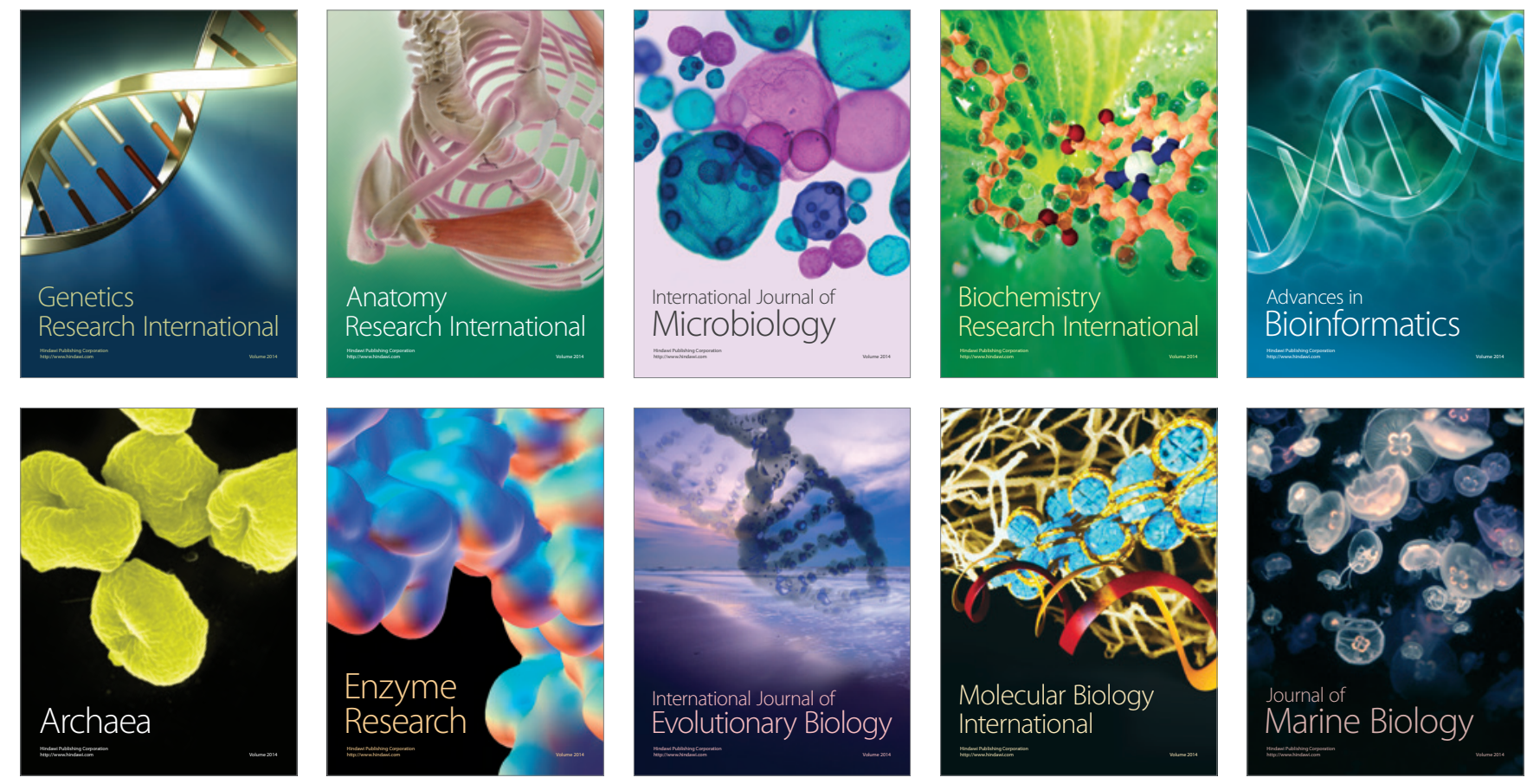